\title{
Psalmy jutrzni i nieszporów w liturgii godzin - dobór, układ i znaczenie teologiczne
}

Psalmy stanowią fundament modlitwy liturgicznej. Jako słowo Boże wyrażają one i podkreślają wymiar eklezjalny liturgii godzin, czyniąc ją modlitwą całego Kościoła. Posoborowa reforma tradycyjnego układu psalmów w officium divinum opierała się na dwóch fundamentalnych pryncypiach, według których dokonano odnowy treści, struktury i znaczenia liturgicznej modlitwy Kościoła. Pierwszym z nich był całkowicie nowy podział psałterza liturgicznego według cyklu czterotygodniowego (Psalterium per quattuor hebdomadas distributum) ${ }^{1}$. Dystrybucja psalmów w liturgii godzin opublikowanej w latach 1971-1972 stała się ogromną nowością w historii oficjum rzymskiego, ponieważ do tej pory starożytną i czcigodną tradycją liturgii łacińskiej, żywą przynajmniej od czasów św. Benedykta, było, aby w ciągu siedmiu dni od niedzieli do soboty odmówione zostały wszystkie ze 150 psalmów ${ }^{2}$. Chociaż przez kilkanaście stuleci zasada recytacji całego psałterza była skrupulatnie przestrzegana we wszystkich wydaniach brewiarza rzymskiego, to jednak z punktu widzenia pastoralnego stanowiła ona poważną przeszkodę w rozumieniu officium divinum jako prawdziwej liturgii chwały, w której bardzo ważną

\footnotetext{
${ }^{1}$ Por. J. Gibert Tarruell, La nouvelle distribution de Psautier dans la Liturgia Horarum, „Ephemerides Liturgicae” 87 (1973), s. 342-345; J. Pascher, Die Psalmen als Grundlage des Stundengebets, „Ephemerides Liturgicae” 85 (1971), s. 260-280; V. Huonder, Die Psalmen in der Liturgia Horarum, Freiburg Schweiz 1991.

${ }^{2}$ Por. P. Fernandez, Elementi verbali della Liturgia delle Ore, [w:] La celebrazione nella Chiesa, ed. D. Borobio, t. 3, Leumann 1994, s. 513.
} 
rolę odgrywa cała wspólnota Kościoła ${ }^{3}$. Drugie pryncypium przyświecające reformie brewiarza rzymskiego po Soborze Watykańskim II dotyczyło lepszego ukazania sensu zarówno literackiego jak i teologicznego, a przede wszystkim chrystologicznego charakteru poszczególnych psalmów ${ }^{4}$. Wierność powyższej zasadzie z jednej strony umocniła tradycyjny dobór psalmów na poszczególne dni i godziny kanoniczne, a z drugiej - doprowadziła do radykalnych zmian, tak że w konsekwencji Kościół rzeczywiście położył większy nacisk na to, aby psalmy odpowiadały lepiej godzinie, konkretnemu świętu czy okresowi liturgicznemu, na jaki zostały wyznaczone. W ten sposób liturgia na nowo dostrzega sens dosłowny i aspekty ściśle literackie psalmów, ukazując jednak jaśniej niż dotychczas ich sens pełny - chrześcijański i chrystologiczny, który od czasów apostolskich stoi u podstaw całej chrześcijańskiej modlitwy kanonicznej, nadaje jej sens i sprawia, że jest ona prawdziwą liturgią, czyli uobecnieniem misterium paschy Jezusa Chrystusa.

\section{Psałterz w układzie czterotygodniowym}

Tradycja odmawiania całego psałterza w ciągu siedmiu dni tygodnia pochodzi z Rzymu i źródła liturgiczne potwierdzają, że była ona zachowywana już w wiekach VI-VII ${ }^{5}$. Żadna z reform officium divinum aż do połowy XX wieku nigdy nie podważyła tej zasady ${ }^{6}$. Tuż przed rozpo-

${ }^{3}$ Niemal każda reforma officium divinum $\mathrm{w}$ ciągu wieków miała podstawy pastoralne i była wołaniem o taką organizację modlitwy liturgicznej Kościoła, w której codzienna recytacja brewiarza nie będzie jedynie przytłaczającym obowiązkiem dla duszpasterzy, ale stanie się pokarmem duchowym dla całego Kościoła.

${ }^{4}$ Por. J. Gibert Tarruell, La nouvelle distribution..., dz. cyt., s. 345-355; Institutio Generalis Liturgiae Horarum, 100-109, 111-113, 121-122, 124-125.

${ }^{5}$ Por. V. Raffa, La Liturgia delle Ore. Presentazione storica, teologica e pastorale, Milano 1990, s. 149.

${ }^{6} \mathrm{~W}$ historii oficjum rytu rzymskiego odnotować można przynajmniej kilka reform brewiarza. Najważniejsze owoce tych reform to: (1) XIII-wieczny brewiarz secundum usum Romanae curiae i jego rozpowszechnienie przez franciszkanów; (2) tzw. Brewiarz Świętego Krzyża (Breviarium Sanctae Crucis) przygotowany przez kard. Quiñonesa w pierwszej połowie XVI wieku; (3) Brewiarz rzymski opublikowany po Soborze Trydenckim przez Piusa V w 1568 roku; (4) Brewiarz rzymski zreformowany przez Piusa X w 1911 roku - por. E. Mateja, Powstanie Brewiarza Rzymskiego i próby jego reformy do papieża Piusa X, [w:] Mirabile Laudis Canticum. Liturgia Godzin - dzieje i teologia. Księga pamiatkowa dedykowana 
częciem Soboru Watykańskiego II zaczęto jednak mówić o możliwości przedłużenia tradycyjnego czasu jednego tygodnia, tak by można było z jednej strony odciążyć nieco obowiązek „odmawiania brewiarza”, a przez to uwolnić modlitwę Kościoła z ram klerykalnych, w jakich od wieków była zamknięta, i uczynić ją bardziej owocną dla wszystkich wiernych? ${ }^{7}$. Ojcowie soboru uznali za uprawnione takie propozycje i w konstytucji o liturgii świętej polecili przedłużenie przestrzeni czasowej, w której należałoby zamknąć recytacje wszystkich psalmów my officium divinum dokonanej po soborze nad kwestiami związanymi z nową dystrybucją psalmów pracowała intensywnie Grupa studyjna nr 3 De psalmis distribuendis pod kierunkiem J. Paschera powołana przez Consilium ad exequendam Constitutinem de Sacra Liturgia $a^{9}$. Ostateczną decyzję, że najbardziej odpowiednim okresem dla recytacji całego psałterza będą cztery tygodnie, podjęto dopiero po kilku latach pracy. Decyzja ta została przedstawiona ojcom I Synodu Biskupów w 1967 roku, a później zawarta w schemacie z marca 1968 roku przygotowanym przez Coetus IX Consilium odpowiedzialny za odnowę brewiarza. Schemat ten przewidywał rozłożenie psalmów na czas czterech tygodni we wszystkich godzinach kanonicznych oprócz komplety ${ }^{10}$.

księdzu biskupowi Stefanowi Cichemu, biskupowi legnickiemu, przewodniczacemu Komisji do Spraw Kultu Bożego i Dyscypliny Sakramentów Episkopatu Polski, red. H. J. Sobeczko, Opole 2008, s. 92-98.

${ }^{7}$ Motyw dążeń w tym kierunku opierał się na przekonaniu, iż tradycyjny podział psalmów w brewiarzu był raczej przeszkodą dla duchowości modlących się niż elementem pozytywnym w tej dziedzinie - por. J. Pascher, Il nuovo ordinamento della Salmodia nella liturgia romana delle ore, [w:] Liturgia delle Ore. Documenti ufficialie studi, Turin 1972, s. 166.

${ }^{8}$ Konst. Sacrosanctum Concilium, 91 stanowi: ,aby rzeczywiście można było zachować układ godzin [...], psalmy należy rozłożyć nie na jeden tydzień, lecz na dłuższy okres". Inne zasady zachowuje liturgia monastyczna - zob. R. M. Leikam, La Liturgia de las Horas monástica renovada en el directorio del Thesaurus Liturgiae Horarum monasticae, Romae 1989; R. M. Leikam, El "Thesaurus Liturgiae Horarum Monasticae” de 1977 y la renovación del Opus Dei Benedictino, „Cuadernos Monásticos” 86 (1988), s. 299-330; L. Leloir, Répartition des psaumes et tradition monastique, „Collectanea Cisterciensia” 41 (1979), s. 254-263.

${ }^{9}$ Por. J. Stefański, Prace redakcyjne nad posoborowa księga Liturgii godzin. Konspekt historyczny, [w:] Mirabile Laudis Canticum..., dz. cyt., s. 115.

${ }^{10}$ Prace consilium dotyczące liturgii godzin i tekstu liturgicznego psalmów zostały szczegółowo opisane w: A. Bugnini, La riforma liturgica (1948-1975), Roma 1997, s. 510-558; por. S. Campbell, From Breviary to Liturgy of the Hours. The Structural Reform of the Roman Office 1964-1971, Collegeville 1995; J. Stefański, Reforma Liturgii Godzin według Vaticanum 
Od momentu publikacji Liturgii godzin czterotygodniowy układ psalmów obowiązuje w okresie zwykłym, w cyklu paschalnym oraz w cyklu Objawienia Pańskiego. Chociaż same psalmy powtarzają się cyklicznie i w ogromnej większości wypadków nie są bezpośrednio zależne od dynamiki roku liturgicznego, to jednak różnice w sposobie ich interpretacji w zależności od okresu liturgicznego lub dnia świątecznego są ewidentne. W liturgii godzin szczególny charakter misterium celebrowanego danego dnia wyraża się bowiem nie tylko w psalmach, ale także w antyfonach oraz innych elementach oficjum, takich jak hymny, czytania, responsoria, prośby itd. Słowa psalmów pozostają niezmienne, lecz w różnych momentach roku liturgicznego ich chrześcijański sens objawia się w Kościele inaczej, odnajduje zawsze pełnię w misterium paschy Jezusa Chrystusa ${ }^{11}$.

Analiza czterotygodniowego układu psalmów podjęta w niniejszym opracowaniu dotyczy jednego tylko aspektu problemu: doboru psalmów do oficjum jutrzni i nieszporów stanowiących „główne części codziennej liturgii" (por. konst. Sacrosanctum Concilium, 89a). Psalmy modlitwy porannej i wieczornej bowiem doskonale oddają sens chrześcijańskiego uwielbienia Boga w liturgii.

\section{Układ psalmodii liturgicznej według godzin kanonicznych}

Psałterz liturgiczny, na którym opiera się całe officium divinum, stanowi bardzo dobrze zorganizowany i przemyślany system doboru konkretnych tekstów. Praktyka Kościoła niemalże od samych początków organizacji modlitwy liturgicznej na Wschodzie i Zachodzie ukazuje, że psałterz liturgiczny dzielono na dwie części, z których pierwsza obejmująca psalmy 1-109 ${ }^{12}$ i 148-150 recytowana była podczas godzin porannych (matutinum

II. Prace redakcyjne, [w:] Liturgia w odnowie, red. K. Konecki, Gniezno 2000, s. 210-230; J. Stefański, Dystrybucja psalmów w posoborowej reformie księgi Liturgii Godzin. Kwestie redakcyjne, „Roczniki Liturgiczne” 1 (2009), s. 449-479.

${ }^{11}$ Por. J. Castellano, La Liturgia de las Horas. Teología y espiritualidad, Barcelona 2003, s. 97.

${ }^{12}$ Przedstawiona tutaj numeracja psalmów jest zgodna z polską edycją Liturgii godzin i oddaje numerację psałterza hebrajskiego. W editio typica z 1971-1972 roku psalmy posiadały numerację zgodną z tzw. Psałterzem gallikańskim, czyli oficjalnym psałterzem Wulgaty pochodzącym od św. Hieronima, a używanym w oficjum rzymskim od XIII wieku. Editio typica altera Liturgii godzin z lat 1985-1987 wraz z tekstem psałterza według 
i laudes), a druga, czyli Ps 110-147, należała do oficjum wieczornego. Można więc powiedzieć, że officium divinum wyróżniało zawsze psalmy odpowiednie do godzin porannych $\mathrm{i}$ wieczornych. W tym podstawowym, a zarazem bardzo schematycznym rozróżnieniu można dostrzec wyraźne korzenie monastyczne, co z kolei prowadzi do wniosku, że jego początków należy szukać w czasach formowania się tzw. cursus psalmodycznego rzymsko-benedyktyńskiego, czyli w VIII wieku, stojącego u podstaw rzymskiego officium divinum następnych kilkunastu wieków ${ }^{13}$. Rozróżnienie na psalmy poranne i wieczorne jest także w pewnym stopniu konkretnym zastosowaniem wspomnianej już podstawowej zasady recytacji wszystkich 150 psalmów w ciągu jednego tygodnia.

Trzeba jednak podkreślić, że obok tej pierwszej zasady pochodzącej z oficjum monastycznego rzymska tradycja liturgiczna była wierna również innej regule, mianowicie wyznaczania konkretnych psalmów na odpowiadające ich treści godziny kanoniczne. Jest ona świadectwem tzw. oficjum katedralnego, którego źródła sięgają pierwszych wieków i pierwszych prób organizacji liturgicznej modlitwy Kościoła zarówno na Wschodzie, jak i na Zachodzie ${ }^{14}$. To z połączenia oficjum monastycznego i katedralnego dokonanego w ostatnich stuleciach pierwszego tysiąclecia chrześcijaństwa zrodziło się oficjum mieszane, którego konkretną realizacją stał się brewiarz. Można więc powiedzieć, że podstawowy podział psałterza liturgicznego wyróżniający w nim psalmy poranne i psalmy wieczorne należy do najbardziej oryginalnej

tzw. Neowulgaty posiada już podwójną numerację psalmów odwołującą się zarówno do Psalterium Gallicanum, jak i do ich tekstu hebrajskiego.

${ }^{13}$ Pierwsze ślady tego podstawowego podziału psałterza liturgicznego można znaleźć już w mieszanym cursus rzymsko-benedyktyńskim z VIII wieku, które odpowiada sposobowi recytacji psalmów według oryginalnego cursus rzymskiego z wieku VI. Zasada podziału psalmów na poranne i wieczorne była w późniejszych wiekach bardzo konsekwentnie zachowywana zarówno w oficjum liturgii rzymskiej, jak i ambrozjańskiej, a także monastycznej (benedyktyńskiej) - por. V. Raffa, L'Ufficio Divino del tempo dei carolingi e il Breviario di Innocenzo III confrontati con la Liturgia delle Ore di Paolo VI, „Ephemerides Liturgicae" 85 (1971), s. 208; J. Gibert Tarruell, La nouvelle distribution..., dz. cyt., s. 327.

${ }^{14}$ Por. R. F. Taft, La liturgia delle ore in oriente e occidente. Le origini dell'ufficio divino e il suo significato per oggi, Roma 2001, s. 53-54. Autor broni tutaj nazwy „oficjum katedralne" wobec często używanego wyrażenia „oficjum parafialne”, gdyż przez wieki życie liturgiczne Kościołów partykularnych skupiało się wokół biskupa. 
tradycji liturgicznej respektowanej zarówno na Wschodzie, jak i na Zachodzie chrześcijaństwa.

\section{Modlitwa o poranku i o zachodzie słońca}

Praktyka modlitwy rano i wieczorem jest jednym z powszechnych fenomenów ludzkiej relacji do Boga (bóstwa), wypływa z religijności naturalnej i spotyka się ją oczywiście w tradycjach religijnych poprzedzających doświadczenie Boga w historii Starego Testamentu. Ogromną zasługą biblijnego Izraela było jednak połączenie modlitwy o poranku i modlitwy wieczornej z konkretnymi wydarzeniami historii objawienia się jedynego Boga człowiekowi ${ }^{15}$. Tradycja chrześcijańska odziedziczyła tę praktykę bezpośrednio z kultury i religii Starego Testamentu tak jak wiele innych odniesień kultycznych, nadając jej własną interpretację teologiczną oraz właściwe sobie ramy organizacyjno-praktyczne. Szczególnie ważne jest, iż w chrześcijaństwie każda modlitwa ma wymiar paschalny, tzn. swoje źródło i pełnię odnajduje w męce, śmierci i zmartwychwstaniu Jezusa Chrystusa. W ten sposób liturgiczna modlitwa poranna oraz wieczorna Kościoła, które z czasem przyjęły „techniczne” nazwy „jutrzni” (łac. laudes) oraz „nieszporów” (łac. vesperae), stały się „dwoma zawiasami”, na których opiera się kanoniczna modlitwa Kościoła ${ }^{16}$.

W jutrzni i nieszporach nakładają się na siebie dwa fundamentalne tematy teologiczne, które konstytuują strukturę tychże godzin oraz determinują ich strukturę i treść teologiczną. Pierwszym z tych tematów jest symbolika światła i ciemności oraz dnia i nocy. Tematyka ta ma bardzo mocny wydźwięk antropologiczny i wyraża powszechne doświadczenie człowieka, w którym poranek i wieczór, czyli momenty przejścia z nocy w dzień (symbol: wschód słońca) i z dnia w noc (symbol: zachód słońca), determinują bieg całego dnia, mocno wpływając na ludzkie życie zarówno na poziomie osobistym, jak i społecznym. Naturalny bieg ludzkiego życia, codzienna aktywność podejmowana na początku dnia oraz zakończenie pracy w celu wieczornego i nocnego

\footnotetext{
${ }^{15}$ Por. S. Rosso, Il segno del tempo nella liturgia. Anno liturgico e Liturgia delle Ore, Torino 2002, s. 437.

${ }^{16}$ Por. tamże.
} 
wypoczynku z jednej strony w sposób naturalny obrazują formę ludzkiej egzystencji, a z drugiej podporządkowują się prawom natury, przez co tworzą w człowieku wielowymiarowe doświadczenie duchowe ${ }^{17}$.

To bardzo wyraźne ukazanie powiązania człowieka i jego doświadczenia z naturą (kosmosem) zostaje jeszcze mocniej podkreślone poprzez drugi temat teologiczny wypływający z praktyki modlitwy o poranku i o zachodzie słońca. Jest to symbolika soteriologiczno-paschalna ukazująca się już w opisie tajemnicy stworzenia i w jakiś sposób także w całej historii zbawienia. W kontekście chrześcijańskim tematyka paschalna zdecydowanie przewyższa tematykę kosmiczno-antropologiczną. Aspekt paschalny liturgicznej modlitwy o poranku i zachodzie słońca został bardzo wyraźnie podkreślony w odnowionej liturgii godzin (por. Ogólne wprowadzenie do liturgii godzin, 38-39 ${ }^{18}$. Można więc powiedzieć, że te dwa podstawowe tematy nieustannie się nakładające i przenikające w jutrzni i nieszporach tworzyły zawsze fundamenty antropologiczne i teologiczne porannej i wieczornej modlitwy liturgicznej Kościoła. W tym kontekście dobór psalmów do jutrzni i nieszporów musiał kierować się bardzo konkretnymi zasadami.

\section{Psalmodia jutrzni}

Psalmodię jutrzni w liturgii godzin tworzą zawsze trzy teksty biblijne, z których dwa pochodzą z Księgi Psalmów, a trzeci umieszony między dwoma psalmami jest kantykiem zaczerpniętym ze Starego Testamentu ${ }^{19}$. Wszystkie psalmy jutrzni zostały dobrane według dwóch podstawowych kryteriów: (1) dostosowanie do odpowiedniej pory dnia oraz (2) motywy pastoralne umożliwiające celebrację jutrzni we wspólnocie wiernych. Wierne zastosowanie tych czynników zmusiło niejako instytucje przygotowujące reformę officium divinum po Soborze Watykańskim II do dość radykalnych innowacji dotyczących dystrybucji

${ }^{17}$ Por. J. Castellano, La Liturgia de las Horas..., dz. cyt., s. 96.

${ }^{18}$ Por. M. Matuszewski, Jutrznia i Nieszpory, [w:] Mirabile Laudis Canticum..., dz. cyt., s. 229-231.

${ }^{19}$ Niniejsze opracowanie skupia się tylko na psalmach, gdyż kantyki biblijne ze względu na swój charakter i pochodzenie wymagają osobnego studium, które pozwoliłoby na dostateczne ich zgłębienie. 
psalmów. Dzięki temu w porannej psalmodii liturgii godzin obok psalmów, które od wieków chrześcijanie odmawiali, modląc się o wschodzie słońca, umieszczono także inne psalmy dobrze odpowiadające znaczeniu antropologicznemu i teologicznemu jutrzni, których jednak tradycja liturgii rzymskiej nigdy w tym miejscu nie lokowała. Ze względów pastoralnych do jutrzni przeznaczone zostały psalmy relatywnie krótkie, bez podziału na sekcje i wybrane spośród tekstów najbardziej znanych, a przez to bliskich wiernym ${ }^{20}$.

Psalmy poranne.Pierwszym psalmem jutrzni jest zawsze jeden $z$ tzw. psalmów porannych (matutinales). W tym miejscu oficjum umieszczono 22 testy, z których 4 występują więcej niż jeden raz ${ }^{21}$. Ich cechą charakterystyczną jest bezpośrednie nawiązanie w tekście do przeżytej nocy lub do dnia, który się rozpoczyna. Niektóre teksty zawierają wzmianki o poranku, o wschodzącym słońcu, o mającej się rozpocząć pracy bądź innych zajęciach człowieka. Chociaż wzmianki i aluzje do antytezy światło-ciemności w psalmach porannych są bardzo częste, to jednak należy pamiętać, że nie zawsze chodzi o światło jako fenomen astronomiczny związany z rozpoczynającym się dniem, ale najczęściej motyw światła jest symboliczny i odnosi się bezpośrednio do Boga. W antropologicznym kontekście znaku te dwie rzeczywistości: światło fizyczne i symboliczne w wielu miejscach się nakładają i przenikają, tworząc wyraźną płaszczyznę symboliczną Bóg-światłość22.

Wśród psalmów porannych zawartych w jutrzni można wyróżnić cztery grupy: (1) psalmy poranne tradycyjne dla liturgii rzymskiej (np. Ps 63, 5, 51, 118, 43, 92, 93, 90, 142); (2) psalmy poranne pochodzące z tradycji współczesnej, czyli zapoczątkowanej przez Brewiarz rzymski z 1911 roku (por. Ps 36, 85, 101); (3) psalmy poranne pochodzące z innych tradycji łacińskich, czyli mozarabskiej i monastycznej (benedyk-

${ }^{20}$ Por. S. Rosso, Il segno del tempo..., dz. cyt., s. 441.

${ }^{21}$ Ps 51 powtarza się w każdy piątek, tzn. czterokrotnie w czterotygodniowym cyklu aktualnego psałterza liturgicznego. Dwa razy recytowane są psalmy 92 (sobota II i IV tygodnia), 118 (niedziela II i IV tygodnia) i 119

${ }^{22}$ Por. S. Rosso, Il segno del tempo..., dz. cyt., s. 441; V. Raffa, La Liturgia delle Ore..., dz. cyt., s. 113. 
tyńskiej) (por. Ps 57, 108 i 119 ${ }^{\mathrm{xIx}}$ ); (4) „nowe” psalmy poranne (por. Ps $42,77,80,84,24,86,87)^{23}$.

Powyższy podział ukazuje, że reforma układu psalmów w liturgii godzin dokonana po Soborze Watykańskim II z jednej strony była wierna najbardziej oryginalnej tradycji oficjum rzymskiego, chociaż z drugiej strony nie bała się pewnych innowacji oraz przesunięć motywowanych zarówno teologicznie, jak i duszpastersko. W ten sposób bardzo wyraźnie objawiła się najważniejsza funkcja liturgiczna pierwszego psalmu jutrzni: ma on wprowadzać wiernych w temat dnia oraz zaprosić do porannego chwalenia Pana - stworzyciela światła, zwycięzcę nad ciemnościami. Należy jednak zaznaczyć wyraźnie, że sam temat uwielbienia Boga zostanie ukazany o wiele wyraźniej w momencie recytacji trzeciego psalmu porannej psalmodii, który skieruje całość porannej modlitwy Kościoła ku pieśni Benedictus - punktu centralnego modlitwy o wschodzie słońca. Psalm poranny ma więc ogromnie ważną rolę w tej wstępującej strukturze chwały i uwielbienia Pana: jest jej początkiem i pierwszym krokiem. Obrzęd okadzenia towarzyszący pieśni Benedictus podczas wspólnotowej celebracji jutrzni tę prawdę jeszcze mocniej uzmysławia i podkreśla ${ }^{24}$.

Psalmy chwały - uwielbienia. Drugim psalmem jutrzni, zamykającym psalmodię poranną, jest zawsze psalm pochwalny, najczęściej wybrany spośród hymnów biblijnego psałterza.Jeśli psalmodię jutrzni można uznać za pewną całość złożoną z trzech pieśni rozpoczynających nowy dzień od modlitwy, wyraźnie widać, że do psalmu typowo porannego i kantyku dodano jeszcze utwór o tematyce chwały i uwielbienia Boga, mimo że często nie zawiera on żadnego odniesienia do pory dnia, w której ta modlitwa jest recytowana. Jak zostało to już podkreślone wyżej, struktura porannej psalmodii jest bardzo charak-

${ }^{23}$ Termin „psalmy tradycyjne” został użyty na określenie psalmów, które w tradycji rzymskiej zapoczątkowanej we wczesnym średniowieczu były częścią konkretnej godziny kanonicznej. „Psalmy z tradycji współczesnej” lub „psalmy współczesne” to psalmy, które weszły w skład danej godziny kanonicznej wraz z reformą brewiarza dokonaną za pontyfikatu Piusa X. Niektóre psalmy po raz pierwszy recytowane są w jutrzni lub nieszporach od momentu opublikowania Liturgii godzin. Na ich określenie używa się terminu „,nowe psalmy” - por. J. Gibert Tarruell, La nouvelle distribution..., dz. cyt., s. 356-369.

${ }^{24}$ Por. S. Rosso, Il segno del tempo..., dz. cyt., s. 445-446. Podobną funkcję posiada okadzenie w czasie Magnificat w nieszporach. 
terystyczna: modlitwa rozpoczynająca dzień otwiera się zawierzeniem Bogu dnia, który rozbłyska blaskiem wschodu słońca, a jej punktem szczytowym jest śpiew uwielbienia za dzieło zbawienia podjęte dla człowieka i świata. W ten sposób sama liturgia prowadzi modlącego się od uczucia wdzięczności za kolejny dzień życia do uwielbienia Boga za stworzenie i zbawienie świata. Ten rodzaj chwały oddawanej Bogu jest centrum i sensem całej liturgicznej modlitwy godzin ${ }^{25}$.

Liturgia horarum pozostawia w jutrzni klasyczne psalmy pochwalne będące częścią oficjum rzymskiego niemalże od początku, ale wprowadza do modlitwy porannej także inne teksty psalmiczne wyrażające pragnienie uwielbiania Pana. W psałterzu liturgicznym znajduje się 20 psalmów pochwalnych, a wszystkie je można z łatwością rozpoznać już od ich pierwszych słów, w których zachęcają do śpiewania i do uwielbiania Pana ${ }^{26}$. Ważne miejsce wśród nich zajmują trzy klasyczne psalmy chwały 148, 149 i 150. Do początków XX wieku, czyli do reformy brewiarza rzymskiego dokonanej przez papieża Piusa X, były one recytowane w jutrzni każdego dnia, stanowiąc pewnego rodzaju ukoronowanie całej modlitwy porannej (matutinum i laudesów) oraz nadając jej rys uwielbienia Boga charakterystyczny dla modlitwy kanonicznej ${ }^{27}$. W liturgii godzin psalmy te pozostawiono $w$ jutrzni wszystkich czterech niedziel (Ps 148 - III tydzień, Ps 149 - I tydzień, Ps 150 - II i IV tydzień), przez co w sposób bardzo intensywny wyrażają one radość ze zmartwychwstania, a także ukazują bardzo wyraźnie paschalny wymiar modlitwy liturgicznej. Można więc powiedzieć, że zarówno ich sens dosłowny, jak i zastosowanie liturgiczne w officium divinum pozwalają, aby trzy klasyczne poranne psalmy chwały odczytywane były jako najwyższy wyraz radości Kościoła rozpoczynającego nowy dzień, śpiewając hymn uwielbienia Stwórcy i Odkupicielowi.

Dwie kolejne grupy hymnicznych psalmów uwielbienia i chwały umieszczonych w jutrzni liturgii godzin pochodzą z tradycji zapocząt-

${ }^{25}$ Por. S. Rosso, Il segno del tempo..., dz. cyt., s. 442.

${ }^{26}$ Por. J. Gibert Tarruell, La nouvelle distribution..., dz. cyt., s. 359-360.

${ }^{27} \mathrm{~W}$ liturgiach wschodnich psalmy 148, 149 i 150 recytowane są do dzisiaj każdego dnia w modlitwie porannej - por. S. Rosso, Il segno del tempo..., dz. cyt., s. 442. 
kowanej przez brewiarz rzymski Piusa X (Ps 117, 135, 145, 146, 147) ${ }^{28}$, bądź po raz pierwszy w historii zostały przeznaczone do tej godziny liturgicznej po Vaticanum II (Ps 8, 19A, 33, 48, 81 i 143) ${ }^{29}$. Wszystkie te psalmy dobrze wpisują się w tradycję liturgii rzymskiej, wyrażając te same myśli i uczucia, co tradycyjne psalmy pochwalne. Wprowadzenie nowych psalmów do jutrzni ukazało, że wymiar uwielbienia i chwały śpiewanej Bogu przez Kościół jest podstawowy w porannej modlitwie liturgicznej. $W$ ten sposób oprócz tematów tradycyjnie zajmujących miejsce w jutrzni, takich jak piękno stworzenia i wielkość Boga, na początku dnia uwielbia się Pana także za Jego dzieła zbawcze dokonane w historii Izraela oraz podkreśla się godność człowieka stworzonego na obraz i podobieństwo Boże.

Ostatnią grupę psalmów zajmujących trzecie miejsce w psalmodii jutrzni stanowią te teksty, które wyrażając uwielbienie i chwałę Pana, zawierają równocześnie bezpośrednie odniesienie do poranka. Liturgia godzin zawiera 9 takich psalmów $(65,67,100,29,47,96,97,98 \text { i } 99)^{30}$.

Psalmy umieszczone na trzecim miejscu psalmodii jutrzni to hymny psałterza, więc można w nich znaleźć styl, terminologię i strukturę typowe dla tej grupy psalmów. Wśród hymnów szczególnego znaczenia dla modlitwy chrześcijańskiej nabrały tzw. kantyki Syjonu i psalmy królewskie zajmujące bardzo ważne miejsce w psalmodii jutrzni. Zdecydowana większość z nich zatrzymuje się na czystym uwielbieniu Boga bez nawiązania do pory dnia, w której recytuje sięjutrznię. Stanowi to bardzo wyraźną cechę odróżniającą psalmy poranne od psalmów uwielbienia

${ }^{28}$ Psalmy 117, 143, 145, 146, 147 są hymnami, które uwielbiają Pana w Jego dziełach. Pierwsze słowa każdego z nich zapraszają do uwielbienia Boga, determinując w ten sposób ich charakter i rodzaj literacki. Łaciński tekst liturgiczny powyższych psalmów obfituje w przyimki względne „qui” oraz w konstrukcje przyczynowe ze spójnikami „quoniam” oraz „quia”, ukazując w ten sposób motywy chwalenia Boga. Są nimi: stworzenie, zbawienie, opieka nad Izraelem, Boże królestwo i miłosierdzie. Oto początek każdego z tych psalmów według ich tekstów zawartych w editio typica Liturgii godzin: „Laudate Dominum, omnes gentes, collaudate eum omnes populi” (Ps 117); „Laudate nomen Domini, laudate, servi Domini” (Ps 134); „Lauda, anima mea, Dominum, laudabo Dominum in vita mea, psallam Deo meo, quamdiu fuero” (Ps 145); „Laudate Dominum, quoniam bonum est psallere Deo nostro, quoniam iucundum est celebrare laudem" (Ps 146); „Lauda, Ierusalem, Dominum, collauda Deum tuum, Sion” (Ps 147).

\footnotetext{
${ }^{29}$ Por. J. Gibert Tarruell, La nouvelle distribution..., dz. cyt., s. 360.

${ }^{30}$ Por. tamże.
} 
i wskazującą na ich zupełnie różny cel. Celem psalmów uwielbienia jest niejako zamknięcie psalmodii w formie wielkiej eksplozji chwały z jednoczesnym otwarciem nowej drogi, która poprzez słowo Boże doprowadzi do szczytu całej porannej modlitwy liturgicznej, jakim jest śpiew kantyku ewangelicznego Benedictus.

Kończąc analizę obecności i funkcji liturgicznej psalmów w jutrzni, należy podkreślić, że ich układ oraz schemat całej grupy psalmodycznej respektują dwa bardzo wyraźne kryteria. Pierwsze z nich ukazuje swoistego rodzaju wstępujący charakter samej psalmodii: od psalmu podkreślającego teologiczne znaczenie poranka nowego dnia poprzez kantyk Starego Przymierza dochodzi się do hymnu uwielbienia i chwały koronującego i zamykającego całą poranną triadę psalmodyczną. Drugim bardzo wyraźnym kryterium zastosowanym przy doborze psalmów jutrzni jest wierność tradycji oficjum rzymskiego dotyczącej psalmów uważanych za najbardziej odpowiedni dla jutrzni ${ }^{31}$ połączona z odwagą dokonania koniecznych przesunięć lub wprowadzenia takich psalmów, które mimo że nigdy nie były częścią modlitwy porannej, to się do niej najlepiej nadają. Tego rodzaju operacje dokonane w procesie reformy officium divinum, trudne do zaakceptowania dla osób przyzwyczajonych do tradycyjnego układu psalmów w brewiarzu rzymskim, pozwalają jednak podkreślić i w wielu przypadkach także po prostu odkryć nowe wymiary chrześcijańskiego znaczenia psalmów, szczególnie jeśli chodzi o ich sens teologiczny.W ten sposób tematyka paschalna, chrystologiczna, soteriologiczna czy eklezjalna - tak bardzo tradycyjna w chrześcijańskiej interpretacji psalmów - może stać się o wiele łatwiej dostrzegalna w celebracji liturgii godzin we wspólnocie Kościoła. Pozostałe zaś elementy officium divinum, takie jak antyfony, tytuły czy tzw. kolekty psalmiczne, jeszcze mocniej ukazują wymiary teologiczne zawarte już w samym tekście psalmów. Można więc śmiało stwierdzić, że zarówno tematyka, jak i cechy literackie przedstawionych psalmów jutrzni usprawiedliwiają w sposób pełny miejsce, jakie zajmują one w liturgii godzin odnowionej po Soborze Watykańskim II.

${ }^{31}$ Różne metody dystrybucji psalmów w psałterzu liturgicznym w ciągu wieków zostały przedstawione w sposób schematyczny w: V. Raffa, La Liturgia delle Ore..., dz. cyt., s. 216-219. 


\section{Psalmodia nieszporów}

Struktura liturgicznej modlitwy wieczornej, jej znaczenie, a także dobór psalmów oparte są na tych samych podstawach kosmiczno-antropologicznych, co odpowiednie do nich elementy jutrzni. Do naturalnej symboliki: światło i ciemność oraz dzień i noc należy jednak dodać także tematykę czysto teologiczną. Chrystus - światłość świata, zwycięstwo Chrystusa nad śmiercią i ciemnościami, wypełnienie się historii zbawienia są to jedynie niektóre wiodące idee od wieków związane z liturgiczną modlitwą Kościoła o zachodzie słońca ${ }^{32}$. W ten sposób tematyka nieszporów koncentruje się wokół następujących idei: antropologiczne i teologiczne napięcie między światłem i ciemnością, przemijanie czasu, ofiarowanie Panu zakończonego właśnie dnia pracy, żal za popełnione grzechy, powierzenie się w ręce Boga wobec rozpoczynającej się nocy, oczekiwanie na kolejny dzień jako pamiątkę zmartwychwstania Chrystusa ${ }^{33}$.

Podobnie jak w jutrzni, psalmodia nieszporów zawiera trzy jednostki psalmodyczne, chociaż sam ich układ jest inny. Pierwsza i druga jednostka to psalmy, a trzecia - kantyk z Nowego Testamentu. Niestety sam schemat doboru poszczególnych psalmów w nieszporach nie jest do końca jasny, gdyż miejsce, jakie konkretne psalmy zajmują w schemacie nieszporów, nie wynika, jak to było w przypadku jutrzni, z ich charakterystyki literackiej lub tematyki zgodnej z wieczorną porą dnia, ale raczej z tradycji modlitwy chrześcijańskiej i z samego układu psalmów w psałterzu biblijnym. W niektórych wypadkach najbardziej charakterystyczny psalm, zwany psalmem wieczornym (lucernarius), zajmuje pierwsze miejsce w psalmodii, w innych - drugie, a zdarza się nierzadko, że danego dnia psalmu tego nie ma wcale lub liturgia proponuje aż dwa psalmy tego typu. Niektórzy autorzy uważają, że dla jaśniejszego ukazania struktury i charakteru modlitwy wieczornej by-

${ }^{32}$ Por. R. Taft, Teologia della Liturgia delle Ore, [w:] Scientia Liturgica. Manuale di Liturgia, direzione di A. J. Chupungco, t. 5, Casale Monferrato 1998, s. 150-165.

${ }^{33}$ Na temat teologii nieszporów w tradycji chrześcijańskiej zob. R. Taft, "Ringrazimento per la luce". Verso una teologia dei vespri, [w:] Oltre l'oriente e l'occidente. Per una tradizione liturgica viva, Roma 2001, s. 173-200. 
łoby dobrze, aby oficjum nieszporów rozpoczynało się zawsze psalmem wieczornym, tak jak psalm poranny rozpoczyna zawsze oficjum jutrzni ${ }^{34}$.

Psalmy recytowane w nieszporach można podzielić na kilka grup. Pierwsza $\mathrm{z}$ nich to klasyczne psalmy wieczorne recytowane $\mathrm{w}$ tym miejscu niemalże od początku istnienia psalmodii liturgicznej. Jak zostało to już podkreślone wyżej, liturgia za wieczorne uważała zawsze psalmy, które w biblijnym psałterzu tworzyły ostatnią grupę tekstów, czyli Ps 110-147. Ich tradycyjne miejsce w historii oficjum rzymskiego było praktycznie niezachwiane aż do reformy liturgicznej dokonanej po Vaticanum II. W ten sposób przez wieki interpretacja liturgiczna psalmów wieczornych była jednoznaczna i nie przedstawiała większych trudności ${ }^{35}$. Liturgia godzin zachowała tradycję recytowania w nieszporach psalmów należących do grupy wieczornych (w formie odziedziczonej po poprzednim brewiarzu Piusa X), wyłączając spośród nich jedynie pięć tekstów (Ps 120, 128, 129, 133 i 140) i umieszczając je w modlitwie w ciągu dnia czwartego tygodnia. Psalmy 131 i 132 nato-

${ }^{34}$ Por. J. Gibert Tarruell, La nouvelle distribution..., dz. cyt., s. 362. Jak zostało to ukazane wyżej, pierwszym psalmem jutrzni jest zawsze psalm poranny, a trzecim - psalm uwielbienia. Tak jasnej i konsekwentnej struktury nie ma jednak w nieszporach.

${ }^{35}$ Oficjum monastyczne (benedyktyńskie) od czasów reguły św. Benedykta było wierne zasadzie, według której w nieszporach codziennie recytowano cztery psalmy według ich numeracji w psałterzu biblijnym, począwszy od Ps $110 \mathrm{w}$ niedzielę aż do Ps 147 w sobotę. Niektóre jednak psalmy z grupy 109-147 zostały wykluczone z modlitwy wieczornej, gdyżuważane były za bardziej odpowiednie do innych godzin. W ten sposób Ps 118 i 142 umieszczono w jutrzni, Ps 119-128 w Horae minores, a Ps 134 stał sie klasycznym psalmem komplety. Brewiarze średniowieczne oraz brewiarz Piusa V z 1568 roku zawierające strukturę psalmodyczną uformowaną w czasach karolińskich zwiększyły liczbę psalmów w nieszporach do pięciu. Aby to osiągnąć, dołączono do nieszporów także Ps 119-128. Inne psalmy pozostały na swoim miejscu. Ważną zmianą okazała się reforma organizacji psałterza liturgicznego, której owocem był Brewiarz rzymski opublikowany w 1911 roku. Papież Pius X zdecydował o zmianie miejsca niektórych psalmów w oficjum nieszpornym. Od tego czasu tradycyjnych psalmów 117, 135, 145, 146, 147 nie recytowano więcej podczas liturgicznej modlitwy wieczornej, ale na zakończenie jutrzni. Aby jednak w psalmodii wieczornej pozostała stała liczba pięciu psalmów, reforma Piusa X rozpoczęła nową zupełnie tradycję w liturgii rzymskiej: niektóre psalmy po raz pierwszy zostały podzielone na sekcje i przestały być recytowane w całości. W ten sposób w Brewiarzu rzymskim z 1911 roku psalmy 135, 138 i 143 podzielono na dwie sekcje, a psalm 144 - nawet na trzy - por. V. Raffa, La Liturgia delle Ore..., dz. cyt., s. 216-219; V. Raffa, Dal Breviario di Quignonez alla Liturgia delle Ore di Paolo VI, [w:] Liturgia delle Ore. Documenti ufficialie studi, dz. cyt., s. 289-362; V. Raffa, L'Ufficio Divino..., dz. cyt., s. 206-259. 
miast recytowane są zarówno w nieszporach, jak i w godzinie czytań. Należy także zaznaczyć, że w momencie podjęcia decyzji o dystrybucji psałterza liturgicznego według schematu czterotygodniowego okazało się konieczne dołączenie do grupy klasycznych psalmów wieczornych pewnych psalmów, które w przeszłości były częścią oficjów innych godzin liturgicznych. W tej grupie znajdują się psalmy interpretowane w tradycji jako odnoszące się do Chrystusa (Ps 41, 16, 21, 30, 46, 71, 45 i 62) lub odczytywane w kluczu parenetycznym (Ps 11, 15, 32, 48). Są to również psalmy wieczorne, ale motywem uznania ich za takie nie była tradycja liturgicznej modlitwy Kościoła, lecz ich treść, rodzaj literacki, a nade wszystko znaczenie teologiczne ukazywane przez poprzedzające je tytuły i wersety, a także antyfony.

Wśród tradycyjnej grupy psalmów wieczornych bardzo charakterystyczne są tzw. psalmy lucernarium, których śpiew przez wieki towarzyszył obrzędowi rozpalenia światła na początku celebracji nieszporów. Ślady tego obrzędu zwanego lucernarium można znaleźć zarówno na Wschodzie, jak i na Zachodzie chrześcijaństwa ${ }^{36}$. Wśród tradycyjnych psalmów z tej grupy można wyróżnić 10 tekstów. Są to psalmy $141,142,110,112,113,132,27,119^{\mathrm{xIV}}, 67,130^{37}$. W historii oficjum rzymskiego zajmowały one różne miejsca w różnych godzinach kanonicznych, ale w czasie posoborowej reformy brewiarza wszystkie one wróciły do nieszporów ${ }^{38}$. Liturgia horarum jest w tym sensie wierna zarówno swojej własnej tradycji liturgicznej, jak i innym liturgicznym tradycjom chrześcijańskim ${ }^{39}$. Psalmy lucernarium zawsze nawiązują do światła: zarówno tego fizycznego w znaku zachodzącego słońca, jak i do

\footnotetext{
${ }^{36} \mathrm{Na}$ temat obrzędu lucernarium zob. J. Pinell, Vestigis del lucernari a Occident, [w:] Liturgica. Cardinali I. A. Schuster in memoriam, t. 1, Montserrat 1956, s. 91-148; J. Pinell, El Mattutinarum en la Liturgia Hispana, „Hispania Sacra” 9 (1956), s. 61-85. Wydaje się, że jednym z ciekawszych rozwiązań pastoralnych dotyczących uczestnictwa wiernych w nieszporach mógłby być powrót do obrzędu lucernarium w celebracji wspólnotowej. Niektóre wspólnoty żyjące rytmem liturgii godzin obrzęd ten podtrzymują.

${ }^{37}$ Por. J. Gibert Tarruell, La nouvelle distribution..., dz. cyt., s. 362-363.

${ }^{38}$ Por. V. Raffa, La Liturgia delle Ore..., dz. cyt., s. 216-219.

${ }^{39}$ Wśród liturgii chrześcijańskiego Zachodu obrzęd lucernarium miał szczególne znaczenie przede wszystkim w nieszporach tradycji ambrozjańskiej i mozarabskiej - por. R. M. Leikam, La Liturgia delle Ore nell'Occidente non romano, [w:] Scientia Liturgica..., dz. cyt., t. 5, s. 141.
} 
symbolicznego - Bożego światła, które świeci i rozwiewa lęk budzący się w ciemnościach, a którego najwyższą manifestacją był poranek Wielkanocy. W ten sposób psalmy lucernarium razem z klasycznymi psalmami wieczornymi są świadkami najbardziej oryginalnej teologii nieszporów ukazującej symbolikę światło-ciemność jako perspektywę kosmiczno-antropologiczną prawdy o zmartwychwstaniu Chrystusa rozumianym jako zwycięstwo światła nad ciemnością. Chrześcijanie mogą być jej pewni, wpatrując się w zachodzące słońce, które o poranku znowu powróci, przynosząc światło. Psalmodia nieszporów ma więc bardzo wyraźny charakter paschalny. Gdy do samej treści psalmów dołączy się także ich interpretację poprzez antyfony oraz tzw. „tytuły” i „kolekty psalmiczne”, tenże aspekt jest jeszcze wyraźniej widoczny.

Obecny układ psalmodii nieszporów jest więc rezultatem bardzo odważnej i głębokiej odnowy liturgicznej modlitwy Kościoła dokonanej w czasie reformy po Vaticanum II. Przez wieki tradycja rzymska nakazywała recytować w nieszporach 35 psalmów w ciągu tygodnia. Obecnie w nieszporach Kościół umieszcza 43 psalmy. Tworzą one 56 jednostek, gdyż tradycyjny wieczorny Ps 110 recytowany jest w II nieszporach wszystkich czterech niedziel, a 10 psalmów zostało podzielonych na dwie sekcje. Chociaż schematy, według których dokonywano dystrybucji psalmów, w wielu wypadkach są nowe w kontekście historii oficjum rzymskiego, to jednak dzisiaj psalmodia nieszporów wyraża bardzo jasno podstawową teologię modlitwy w blasku zachodzącego słońca ${ }^{40}$.

${ }^{40}$ Najbardziej kontrowersyjna z punktu widzenia struktury officium divinum i dystrybucji psalmów reforma Brewiarza rzymskiego dokonana przez kardynała Quiñonesa w pierwszej połowie XVI wieku nie może być uznana za wystarczającą. W opublikowanym przez niego w roku 1535 Breviarium Sanctae Crucis każda godzina złożona była z trzech psalmów, lecz w ich podziale na poszczególne dni tygodnia i godziny liturgiczne ważniejsza wydawała się sama liczba psalmów od ich treści i tradycyjnych interpretacji. Można więc powiedzieć, że dobór psalmów w brewiarzu Quiñonesa był arbitralny i sztuczny. Używanie tego brewiarza mimo wielkiego entuzjazmu, z jakim spotkał się w środowiskach duchownych swojej epoki (w latach 1535-1568 ukazało się aż 113 edycji), zostało zakazane przez papieża, a jego miejsce bardzo szybko zajął brewiarz rzymski odnowiony po Soborze Trydenckim, w którym dystrybucja psalmów w pełni odpowiadała kilkusetletniej już tradycji oficjum rzymskiego - por. V. Raffa, Dal Breviario di Quignonez..., art. cyt., s. 294. 


\section{Podsumowanie}

Układ i dystrybucja psalmów w jutrzni i nieszporach liturgii godzin jest owocem dogłębnej refleksji historycznej, teologicznej i pastoralnej nad chrześcijańskim wymiarem psałterza. W posoborowej odnowie liturgii godzin w doborze odpowiednich psalmów do konkretnych godzin kanonicznych zastosowano podstawowe reguły interpretacji psałterza w modlitwie liturgicznej, respektując ich charakterystyki literackie, ale zdecydowanie stawiając na pierwszym miejscu ich znaczenie teologiczne rozbłyskujące pełnym blaskiem w świetle Jezusa Chrystusa i tajemnicy Jego paschy.

W ten sposób poranna i wieczorna modlitwa Kościoła nie ogranicza się jedynie do recytowania psalmów według ich porządku w psałterzu biblijnym ani do naturalnej symboliki kosmicznej światła dającego siłę, gdy rodzi się nowy dzień, i napełniającego pokojem w obliczu zapadającego zmroku. Psalmy celowo dobrane do jutrzni i nieszporów sprawiają, że poranek i wieczór każdego dnia staje się doskonałą przestrzenią do kontemplacji osoby i zbawczego dzieła Jezusa Chrystusa, który poprzez liturgię jest nieustannie obecny i działa w modlącym się Kościele.

Rzeszów

KS. TOMASZ BAĆ

\section{Słowa kluczowe}

Liturgia godzin, officium divinum, liturgia horarum, brewiarz, psalmy, jutrznia, nieszpory, Sobór Watykański II, psalmodia liturgiczna

\section{Summary}

The psalms of the morning and evening prayer in the Liturgy of the Hours - selection, distribution and theological meaning

The selection of psalms for the Morning and Evening prayer of the Roman Liturgy of the Hours has been profoundly reconsidered on the basis of their clear literary, anthropological and theological criteria. Although both the Morning and the Evening prayers are based on the fundamental cosmic-anthropological symbolism: light and darkness, day and night, their genuine meaning is of theological and paschal nature. The psalms of the Morning prayer express the joy of Church on the threshold of a new day and the veneration of God for his creation of the world and salvation of people. The 
psalms of the Evening prayer are the song of Church which recognizes the announcement of the rising Jesus Christ in the sign of the declining sun. Thus the basic reference to the selection of the psalms for the Liturgy of the Hours is their full significance - paschal and christological.

\section{Keywords}

Liturgy of the Hours, Divine Office, Breviary, psalms, Morning prayer, Evening prayer, Vatican II, liturgical psalmody 